\title{
IMPROVING ACHIEVEMENT MOTIVATION FOR MENTALLY DISABLED STUDENTS AT SCHOOL FOR EXCEPTIONAL CHILDREN (SLB) YPAC Pangkalpinang
}

\author{
Diah Rina Miftakhi \\ STKIP Muhammadiyah Bangka Belitung \\ diah.rinamiftakhi@stkipmbb.ac.id \\ Widati Amalin Ulfah \\ STKIP Muhammadiyah Bangka Belitung \\ widati.amalinulfah@stkipmbb.ac.id
}

\begin{abstract}
This research is globally aimed to improve the achivement motivation for the mentally disabled students. The specific objectives of this research are to improve: (1) students learning achievement for the mentally disabled students; (2) learning achievement for the mentally disabled students in SLB YPAC Pangkalpinang. This research desaign was desaigned with research and development desaign which produce development model of group dynamics learning for exceptional students which can increase achievement motivation for students. The final objective of this research development is producing development learning model based on group dynamics so that teaching and learning process can be more effective, eficient, and interesting. This research will produce development model of group dynamics learning for mentally disabled students so that can increase achievement motivation in exceptional school. This development learning model of group dynamics has three activities, there are learning through dream trees, learning through filling students' identity, and learning through artistic creativity development by drawing and coloring. The result of these three activities of development group dynamics learning model can be used as the source to arrange the learning model especially for mentally disabled students. It can be done so that we can develop the mentally disabled students' potencies and they can reach good achievements in study. Besides that, it can be the source for the teachers to have innovative learning model in teaching mentally disabled students at exceptional school (SLB) YPAC Pangkalpinang.
\end{abstract}

Keywords: mentally disabled students, achievement motivation.

\section{INTRODUCTION}

Every child comes with their own uniqueness by their weakness or their strengths. The general picture that developed in the society, especially in
Indonesia regarding the children potential is often associated with their success in taking the formal education. Children who success in the academic and have a prestation in education are 


\section{BERUMPUIN}

P-ISSN 2622-8831

Berumpun Journal: An International Journal of Social, Politics and Humanities Vol. 2 No. 1 March 2019

considered as intelligent students.Intelligence is often judged by the academic achievement achieved by a child. (Mudjito, 2014: 1).Thus, to achieve high achievement, every child should get a guidance, mentoring, and motivation from their society as well.

Motivation is one of the most important factors in growing a child's interest of learning, especially in studying at school. A child without having a high motivation in learning, cannot achieve a good learning achievement and optimize the abilities.Motivation is a motor for doing something. Motivation is an internal state of an organism (individual), which encourages someone to do somethingMotivation is often interpreted as basic which has a function to encourage someone to do activities, even it is able to multiply the potential. According to Manulang (1982: $10)$, motivation is the motive giving, the motive emergence and things that cause encouragement. Motivation can also be interpreted as a factor that encourages people to do action.

Children with special needs in following the learning process also need motivation from both the school and the family. Without motivation from others, children with special needs will experience difficulties in developing

their potential. As said by Desiningrum (2016: 1) that children with special needs are children who need special treatments because of the developmental disorders and abnormality experienced by children. Children with special needs are children who have physical, mental-intellectual, social, and emotional limitations that significantly influence the process of growth and development.

Special Education or Extraordinary School (SLB) is an education for students who have difficulty in following the learning process because of physical, emotional, mental social disabilities but have special potentials in their intelligence and talent. (Suparno, 2007: 97). Therefore, the role of Extraordinary Schools is very important to provide education for children with special needs. Special needs children desperately need an education which can explore all their potential although they have limitations in learning, knowledge, and skills.

YPAC SLB Pangkalpinang is one of the schools that provide education services for children with special needs. An extraordinary school (SLB) is one of the educational institutions with has the goal not only to fulfill the national education goals but 


\section{BERUMPUIN}

P-ISSN 2622-8831

Berumpun Journal: An International Journal of Social, Politics and Humanities Vol. 2 No. 1 March 2019

also to explore the abilities of students with special needs optimally. (Al Irsyady \& Nugroho, 2015: 13).The classification of children with disabilities as described in the study conducted by Abdullah $\mathrm{N}$ (2013: 6), explains that if it is associated with educational interests, especially in Indonesia, the abnormalities forms experiensingtrouble developmental can be simplified as follows: a) part $A$ is for blind children group, b) part $B$ is for a deafchildren group, c) part $\mathrm{C}$ is for a mentally retarded children group, d) part $D$ is for a disabilities children group, e) part $E$ is for anunsociable children group, $f$ ) part $F$ is for a group of children with abilities above average / superior, g) part $G$ is for a group of children with multiple handicap.

In general YPAC extraordinary school (SLB) Pangkalpinang serves children who experience mental retardation and development from various types of abnormalities: (1) mental disorders: mentally retarded, low-leaner children, (2) physical abnormalities: deaf, physical loss(disabilities), (3) emotional disorders: autism, ADD, and ADHD. YPAC SLB Pangkalpinang always strives to provide the best education for children with special needs by developing all the potentials and talents of each child. This is done because children with special needs also have a lot of potential that can be developed.

The number of students in YPAC SLB in Pangkalpinang City currently reach 93 children, consisting of various developmental obstacles. The most number is students who experience developmental challenged for the type of low-level mental disorder, namely mental retardation. Close to $70 \%$ of students who study at YPAC SLB experience the mental retardation. From the results of interviews with teachers who teach at YPAC SLB, they said that, by the number of students who were almost $70 \%$ experiencing mental retardation, schools have not been able to maximize their potential in each student. Thus, the classical method still used to give the learning process to explore the potential of children with those special needs.

Based on the problems in YPAC SLB Pangkalpinang, this study aims to be able to improve the achievement motivation of children with special needs. Thus, the method will be done to make the learning process unmonotonous and not boring for students. The development of learning model in this group dynamics is also be used by the teachers as the reference 


\section{BERUMPUN}

P-ISSN 2622-8831

Berumpun Journal: An International Journal of Social, Politics and Humanities Vol. 2 No. 1 March 2019

in teaching for improving the ability of mentally retarded children.

\section{RESEARCH METHOD}

The study was designed by using the development research which will produce a learning model of a group dynamics for children with special needs that can improve the achievement motivation for students. The ultimate goal of this development research is to produce a product of learning development models based on group dynamics so the learning process becomes more effective, efficient, and interesting in the teaching and learning process.

The research of learning developing model by a group dynamics on children with special needs to improve the achievement motivation used the Research and Development model of ASSURE consisted of six steps. These steps include:

\section{Analysis of Student Characteristics}

The purpose of this analysis is to find out the problems faced in the learning process and see the extent of the education characteristics for children with special needs

2. Determine the Learning Objectives

The next step is to set the learning objectives to be achieved which will be used to evaluate the effectiveness of the learning process. A learning process is successful if students can achieve their goals optimally.

3.Select the Medias, Methods and Materials

When the learning develop model of group dynamics for children with special needs was selected, the next stage is selecting the media that will be used for the development process. This media selection is done to improve and complete the learning media that has been created.

4. Utilizing the Teaching Materials

Through the teaching materials, teachers will be easier to do the learning process and will be more helpful in learning process. Teaching materials could be made in various forms according to the needs and characteristics of the presented teaching material. Teaching materials are prepared with the aim to provide the teaching materials that meet the needs of learners.

5. Involving students in learning activities

Student involvement can be interpreted as the students activelyparticipatein the teaching 


\section{BERUMPUIN}

P-ISSN 2622-8831

Berumpun Journal: An International Journal of Social, Politics and Humanities Vol. 2 No. 1 March 2019

and learning process. The teacher strives to give students the opportunity to be active in seeking, processing and managing their learning process. To be able to increase student involvement in the teaching and learning process, the teacher can directly be involve with the students both individually and in groups.

6. Evaluation and Revision

Evaluation is a subsystem which is very important and crucial in every education system because evaluation can reflect how far the development or progress in education results. The progress and backwardness of the education quality can be known throughthe evaluation. Moreover, people could know the point of weakness and easily toseek the way to make a change for getting a better education in the future.

In this case, an evaluation is done to know how the developed model has some effects and is effective for the implementation of student learning activities, especially for children with special needs. Furthermore, with an evaluation, the improvements will also be made if there are several things that must be improved in the implementation of media development for learning.

\section{RESULT AND DISCUSSION}

Every student who has physical, emotional, mental, and social disabilities or has the potential for intelligence and/or special talents has the right to participate in inclusive education in certain education institution base on their needs and abilities. Mentally disabled children with special needs seem different in their physic, mental and social emotion. They have special characteristics which cause some adjustments in various fields so they still will get the same rights as other mentally retarded children and those adjustments should be able to optimize their development as same as the other retarded children.

\section{Characteristics of children with mental retardation}

Mentally disabled children are children who have below-average intellectual abilities, in a foreign language, it is known as mental retardation, mentally retarded, mental deficiency, and mentally defective, which all have the same meaning that explains the condition of mentally 


\section{BERUMPUN}

P-ISSN 2622-8831

Berumpun Journal: An International Journal of Social, Politics and Humanities Vol. 2 No. 1 March 2019

retarded children whose intelligence is below on average, those who are followed by the limitations of intelligence and lack of skills in social interaction. 'Tunagrahita' child is also known as mentally retarded because of the limitations of his intelligence, it is difficult to join the classical education programs. (T.Sutjihati Somantri, 1996: 83).

According to Sapariadi (1992: 20), mentally retarded children are "A combination of real symptoms in the development of mentally retarded children; and the most prominent is the late and limited intelligence development, besides that there are some special symptoms in emotional development and in social adjustment. However, the mentally retarded children are they who has the intelligent under the average, besides that they are difficult in adjusting to the environment and thinking about abstract, difficult, and convoluted things (Amin M, 1996: 11).Most of the students who attend Pangkalpinang YPAC SLB are mentally retarded children. Thus, facilitating the school in teaching, YPAC SLB Pangkalpinang makes some class categories base on the characteristics of each child. There are three characteristics of mentally retarded children, including:
1. Characteristics of mild mental retardation

Even though they cannot be as same as normal children of their age, they can still can learn how to read, write, and do a simple count. At the age of 16 years or more, they can learn materials that have the same level of difficulty as grade 3 and grade 5 of elementary school. The learning maturity of reading is achieved at the age of 9 years and 12 years according to the category of the disorder.

2. Characteristics of moderate mental retardation

Mentally disabled children are barely able to learn academic lessons. Language development is more limited than mild mental retardation children. They communicate with a few words. They can read and write, like their own name, address, parent's name, and so on. They know numbers without understanding. However, they still have the potential to take care of themselves. After adults, their intelligence is no more than a normal child aged 6 years. They can do many things under supervision.

3. Characteristics of severe and very severe mental retardation 


\section{BERUMPUIN}

P-ISSN 2622-8831

Berumpun Journal: An International Journal of Social, Politics and Humanities Vol. 2 No. 1 March 2019

Throughout the lives of severe and very severe mentally retarded children will always depend on other people help. They cannot maintain themselves (eating, dressing, toilets, etc. must be helped). They cannot distinguish between dangerous and not dangerous. They also cannot speak, they only speak simple words or signs if they are able to speak. Their intelligence in their adult ages is like the age of 4 years in a normal child. To maintain their physical and health stability, it is better to give them activities.

\section{The learning model development of mentally retarded children}

Despite of having limitations in cognitive development aspects, mentally disabled children still be able developed in other aspects. One aspect that can be developed is the artistic aspect of creativity. There are so many aspects of art that can be extracted from each child. YPAC SLB Pangkalpinang has many students who experiencing the developmental challenge in their cognitive aspects, namely mental retardation. To be able to explore the potential of students who have the mental retardation category, the characteristics of it must be known. By knowing the characteristics of each student, it will be easier for the teacher to provide appropriate learning methods and learning media base on the level of each student ability.

The learning model development was involvedthe elementary school students who are in the mental retardation category from grade 3 to grade 6 . The subjects of this study were 30 people. The development of learning models for mentally retarded children is provided through the group dynamics by using several learning models. The learning model includes:

1. The tree of dreams

This tree of dreams is made from manila paper. In the tree of dream, the students are given pieces of paper with apple's shapes. Then, the students are told to write down the dreams behind the apple-shaped paper. After that, students are told to stick the apple-shaped paper to the tree of dreams. From the activities, it resulted out of 30 students who took part in the activities, there were $85 \%$ of the mentally disabled children had understood and followed the commands. It showed that the ability level of the mentally retarded child in understanding the command is good. The command that must be done is a simple command. This activity was conducted to find out how far the level 


\section{BERUMPUIN}

P-ISSN 2622-8831

Berumpun Journal: An International Journal of Social, Politics and Humanities Vol. 2 No. 1 March 2019

of understanding and concentration of students in carrying out the tasks given by the teacher at the school. From the results of this study, it can be interpreted that mentally retarded children are able to understand the simple commands and in carrying out the instruction, they still need the teacher's mentoring.

2. Filling the Personal Identity

This child's self-identity is provided to determine the extent of their soft motoric skills and social maturity. From the results of the research we conducted from 30 mentally retarded children, only $45 \%$ of children could write their own identity and it was uncompleted. The students only wrote their nicknames and they need to be guided when they wrote it. From those results, it can be concluded that mentally retarded children have a low level of soft motoric skills due to the development of the brain is not develop well.

In the social ability aspects, it showed that each child is not really developed as well. Students are not fully understand about their family members. Most of the mentally retarded child only recognized their family from the physical appearance and got difficult to mention the names of their family members one by one. From those results, it is analyzed that their level of intellectual ability cannot be forced because of the limitation development level, both brain development and physical development.

3. Development of Drawing Creativity / Art

The last development model is by developing the drawing creativity. Each of the children was shared a package of stationery consisted drawing books, pencils, erasers, colored pencils and notebooks. Then, the students were instructed to do a freedrawing by using their own drawing books. After that, theirpictureswere immediately colored using colored pencils. The results of the activities showed the data of $90 \%$ children who experiencing mental retardation couldfinish the task of drawing and coloring well. In addition, mentally retarded children who participated in the research which conducted at YPAC SLB Pangkalpinang City could develop their creativities. They can draw with their own ideas and complete the task until finished. From the results of the students, there were some students who could draw houses, animals, roads, people, scenery and flowers.

Based on the results, it can be concluded that the most effective 


\section{BERUMPUIN}

P-ISSN 2622-8831

Berumpun Journal: An International Journal of Social, Politics and Humanities Vol. 2 No. 1 March 2019

learning model development of group dynamics for mentally retarded children is by exploring the potential of students in terms of their creativity. One of the creativities which can be developed as their potential is letting them create their own creativities base on their creativity levels. One of the creative aspects that can be developed is art creativities, for examples, drawing dan coloring.

\section{CONCLUSION}

The conclusions that can be conveyed from the results of this study is the learning models development of group dynamics for mentally retarded children can be carried out for all elementary school levels. Learning of group dynamics can be given in various styles, types and used through a variety of media. In this research, it has developed three learning development models based on group dynamics to improve the learning motivation of mentally retarded children in YPAC SLB, Pangkalpinang. The learning models of group dynamics development are making the tree of dreams, filling children's identity, and developing artistic creativity. From those three development models of group dynamics, there are two developments that can improve learning achievement motivation for mentally retarded children.

From the various development models which have been learned above, it can be analyzed that every mentally retarded child has a different level of ability. They have various kinds of limitations but there are still some part of abilities that can be developed. One potential that can be developed is the development in non-academic fields. Development in the nonacademic field can explore the potential of each child.

\section{REFERENCES}

Abdullah N. 2013. "Mengenal Anak Berkebutuhan Khusus" Magistra No. 86 Th. XXV Desember 2013 ISSN 0215-9511

Amin, M. 1996. Ortopedagogik Anak Tunagrahita. Jakarta: Depdikbud, Dirjend Pendidikan Tinggi Proyek Tenaga Guru.

Al Irsyadi F.Y, Nugroho Y.S. 2015. "Game EdukasiPengenalanAnggotaTubuh Dan PengenalanAngkaUntukAnakBerkebutuhanKhusus (ABK) TunagrahitaBerbasis Kinect". Prosiding SNATIFKe -2 Tahun 2015ISBN: 978-602-1180-21-1.

Desiningrum D.R. 2016. Psikologi Anak Berkebutuhan Khusus. Yogyakarta: Psikosain. 


\section{BERUIMPUIN}

\section{P-ISSN 2622-8831}

Berumpun Journal: An International Journal of Social, Politics and Humanities Vol. 2 No. 1 March 2019

Manulang, M. 1982. Manajemen dan Personalia. Jakarta : Ghalia Indonesia.

Mudjito. 2014. Memahami Pendidikan Khusus Dan Pendidikan Layanan Khusus Contoh Kasus Pelayanan di Wilayah Pesisir dan Perkotaan. Yogyakarta: Pustaka Pelajar.

Sapariadi, dkk. 1992. Mengapa Anak Berkelainan Perlu Mendapat Pendidikan. Jakarta: Balai Pustaka.

T.Sutjihati Somantri. 1996. Psikologi Anak Luar Biasa. Jakarta: Depdikbud, Dirjend Pendidikan Tinggi Proyek Tenaga Guru. 